\title{
OPEN Heavy metals content in ashes of wood pellets and the health risk assessment related to their presence in the environment
}

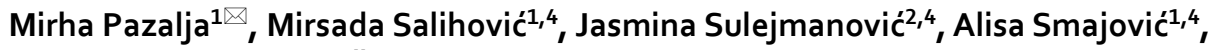 \\ Sabina Begić ${ }^{2,4}$, Selma Špirtović-Halilovic ${ }^{1,4}$ \& Farooq Sher ${ }^{3,4}$
}

Efforts to reduce air pollution in developing countries may require increased use of biomass fuels. Even biomass fuels are a sustainable alternative to fossil fuels there is limited quantitative information concerning heavy metal content in their ashes. Therefore, this study focuses on the determination of the heavy metal concentrations in wood pellet ash obtained from the combustion of 10 pellet brans from Bosnia and Herzegovina and Italy, the effects of adding the ashes to soils, and the assessment of health risk assessment. Ash content was determined by gravimetric method. The amount and composition of ash remaining after combustion of wood pellets varies considerably according to the type of biomass and wood from which the pellet is made. Samples were prepared by wet digestion using $\mathrm{HNO}_{3}$, and heavy metals are determined by atomic absorption spectroscopy-flame and graphite furnace. The results showed that the lowest concentration in ashes was obtained for Co $0.01 \mathrm{~g} \mathrm{~kg}^{-1}$ and the highest for Fe $571.63 \mathrm{~g} \mathrm{~kg}^{-1}$. The Hazard Index ( $\left.\mathrm{HI}\right)$, calculated for noncancerous substances for children was 2.23E-01, and the total Risk index was 4.54E-05. As for adults, $\mathrm{HI}$ was $1.51 \mathrm{E}-02$, while the Risk index value was $3.21 \mathrm{E}-06$. Human health risk calculated through $\mathrm{HI}$ and Risk index for children and adults associated with analyzed pellets is not of significant concern. The calculated enrichment factor and metal pollution index for wood pellet ashes indicate the risk of soil contamination with heavy metals. From this point of view, analyzed samples of ashes could be a serious contaminant of soil, so further monitoring is required.

The energy production from wood biomass fuels is a sustainable and environmentally friendly alternative to the use of fossil fuels. Biomass refers to any material produced by organisms of animal and plant origins, such as wood, agricultural residues, and animal residues, which can be used as fuel for energy production ${ }^{1}$. Wood as an energy source is increasingly returning to use and wood pellets as one of the most common solid biomass wares are specially used for energy intents. Pellet is a cylindrical organic fuel produced by compressing biomass fuel, which usually consists of wood waste, agricultural biomass, merchandisable grasses, and forestry remains ${ }^{2}$. Wood pellets fuel quality as well the efficiency of the devices which capture and store combustion products is of great importance. The incinerating of wood pellets is a simple household available source of heat and energy which generated waste, primarily $a^{3}{ }^{3}$. Ashes are the proportion of small particles of material produced by the combustion of solid fuels like coal, wood, and other high-energy substances. The composition of ashes depends on the type of material burned and the boilers used in the process ${ }^{4,5}$. The ash produced during the burning of wood pellets in households represents an additional and needless problem on the environment due to nonselective collection and landfill disposal. However, the ash produced from wood biomass is possible to apply in agriculture as soil fertilizer because of constituted nutrients and vital inorganic components such as $\mathrm{C}, \mathrm{O}, \mathrm{H}, \mathrm{Ca}$, $\mathrm{K}$ and, less frequently, $\mathrm{N}, \mathrm{S}, \mathrm{Mg}, \mathrm{P}, \mathrm{Cl}, \mathrm{Na}, \mathrm{Mn}, \mathrm{Zn}, \mathrm{Fe}, \mathrm{B}, \mathrm{Cu}$ or Mo. This application improves soil balance by providing a liming effect (alkaline $\mathrm{pH})^{6,7}$. But, the pollution problem caused by ashes disposing is especially serious because they can contain high heavy metal concentrations ${ }^{8}$. Heavy metals are natural elements with relatively

${ }^{1}$ University of Sarajevo-Faculty of Pharmacy, Zmaja od Bosne 8, 71000 Sarajevo, Bosnia and Herzegovina. 'University of Sarajevo-Faculty of Science, Zmaja od Bosne 33-35, 71000 Sarajevo, Bosnia and Herzegovina. ${ }^{3}$ School of Science and Technology, Nottingham Trent University, Nottingham NG11 8NS, UK. ${ }^{4} T h e s e$ authors contributed equally: Mirsada Salihović, Jasmina Sulejmanović, Alisa Smajović, Sabina Begić, Selma Špirtović-Halilović and Farooq Sher. ${ }^{\circledR}$ email: mirha.pazalja@ffsa.unsa.ba 


\begin{tabular}{|l|l|l|l|l|l|l|}
\hline Sample & $\begin{array}{l}\text { Energetic value } \\
(\mathbf{k W h} / \mathbf{k g})\end{array}$ & Wood type & Ashes declared (\%) & Ashes founded (\%) & $\begin{array}{l}\text { Moisture declared } \\
(\%)\end{array}$ & $\begin{array}{l}\text { Country of } \\
\text { origin }\end{array}$ \\
\hline S1 & 5 & $\begin{array}{l}\text { Beech (80\%), oak } \\
(20 \%)\end{array}$ & 0.64 & 1.11 & 5.24 & B\&H \\
\hline S2 & 5.45 & Beech, fir & 0.60 & 0.96 & 10.00 & B\&H \\
\hline S3 & $4.58-5.27$ & Beech & $\leq 0.70$ & 0.71 & $\leq 10.00$ & Italy \\
\hline S4 & 5.1 & $\begin{array}{l}\text { aOak, beech, ash } \\
\text { tree, hornbeam }\end{array}$ & 0.75 & 1.56 & 8.40 & B\&H \\
\hline S5 & 4.88 & $\begin{array}{l}\text { aOak, beech, ash } \\
\text { tree, hornbeam }\end{array}$ & $<1.20$ & 1.29 & $<10.00$ & B\&H \\
\hline S6 & 5.20 & $\begin{array}{l}\text { Spruce (50\%), } \\
\text { beech (50\%) }\end{array}$ & $<1.00$ & 2.36 & $<10.00$ & B\&H \\
\hline S7 & 4.83 & Coniferous wood & 0.40 & 1.56 & 7.40 & B\&H \\
\hline S8 & 5.10 & $\begin{array}{l}\text { Spruce (50\%), } \\
\text { beech (50\%) }\end{array}$ & $<0.70$ & 1.00 & $\leq 8.00$ & B\&H \\
\hline S9 & 4.60 & Beech, spruce, fir & - & 1.21 & $\leq 10.00$ & B\&H \\
\hline S10 & 5.20 & $\begin{array}{l}70 \% \text { Beech, } 30 \% \text { fir } \\
\text { and spruce }\end{array}$ & $<0.70$ & 2.14 & $<10.00$ & B\&H \\
\hline
\end{tabular}

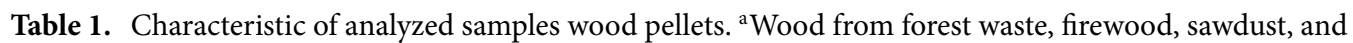
other wood processing waste.

high density, atomic numbers, and atomic weight. Their multiple uses in industry, households, agriculture, medicine, and technology raise concerns about their potential impact on human health and the environment ${ }^{9}$. Heavy metals such as $\mathrm{Cd}, \mathrm{Hg}, \mathrm{Pb}, \mathrm{Cr}, \mathrm{Ni}$, and As, present even at very low concentrations have harmful effects on the body causing acute and chronic toxicity in humans ${ }^{10,11}$. Therefore, for environmental protection, as well as to provide sufficient clean air and soil levels, heavy metals should be kept at a safe level ${ }^{12}$. This is the main reason why monitoring of different energy intents (i.e. fuel, biomass, wood pellets, coal) should be performed based on analyzing the heavy metal content in their ashes. The house heating in Bosnia and Herzegovina (B\&H) is generally based on using solid, conventional fuels. The requirements for using renewable energy sources have increased the contribution of the wood biomass use which results in rises in the quantity of the waste incinerated, primarily in the form of ashes. Many researchers have provided results about the physical and chemical characteristics of wood pellets, but such studies are still lacking for wood pellets used in $\mathrm{B} \& \mathrm{H}^{13,14}$. Additionally, some authors have found high concentrations of some heavy metals in particulate matter found in the air or street dust of B\&H. They only propose that wood pellet from household is one of the sources of heavy metals in the ambient air or street dust of $\mathrm{B} \& \mathrm{H}$, but the main information about heavy metal content in used pellets is missing ${ }^{15-17}$. Considering the above, this study is aimed to determine the heavy metal concentrations in the ashes produced by combusting ten wood pellet samples often used in $\mathrm{B} \& \mathrm{H}$. Furthermore, the novelty of the work is related to health risk assessment associated with the presence of polluted ashes in the environment for children and adult residents in the region. Obtained results could be used in future work to find out how much wood pellets contribute to the total air pollution.

\section{Materials and methods}

Collection of the samples. Ten (10) wood pellet samples were purchased from a different location in $\mathrm{B} \& \mathrm{H}$, of known suppliers from the market (supermarkets, garden shops, and gas stations). The samples were accompanied by a declaration describing that nine of them were originated from $\mathrm{B} \& \mathrm{H}$, and one of them was from Italy. Characteristics of collected wood pellet samples (type of wood, energetic value, declared moisture, declared and determined ash amount) are listed in Table 1. All of the samples were analyzed for moisture and ash content. Additionally, in ash samples of mentioned wood pellets, heavy metal concentration ( $\mathrm{Cd}, \mathrm{Co}, \mathrm{Cr}, \mathrm{Cu}$, $\mathrm{Fe}, \mathrm{Mn}, \mathrm{Ni}, \mathrm{Pb}$, and $\mathrm{Zn}$ ) was determined.

All pellet samples were originated from B\&H, purchased from different cities, often used for house heating, instead of sample S3 which was from Italy.

Ash determination of wood biomass samples. The wood pellet samples were oven-dried at $105^{\circ} \mathrm{C}$ for $24 \mathrm{~h}$. The content of ash was determined by gravimetric method according to the procedure published by Pan and Eberhardt ${ }^{18}$ as follows: pellet samples, $1 \mathrm{~g}( \pm 0.1 \mathrm{mg})$ of each was weighed into a previously annealed ceramic pot $\left(\mathrm{m}_{1}\right)$ and burned in a muffle furnace (Nabertherm) for one hour at $300{ }^{\circ} \mathrm{C}$, following by increasing the temperature to $400{ }^{\circ} \mathrm{C}$ for one hour more and then burning the samples for next six hours at $550{ }^{\circ} \mathrm{C}$. The procedure is repeated until a constant mass $\left(\mathrm{m}_{2}\right)$ was reached. The ash content is determined by the Eq. (1):

$$
\text { Ash content, } \%=\frac{\left(\mathrm{m}_{2}-\mathrm{m}_{1}\right)}{\mathrm{m}_{\text {sample }}} \times 100 .
$$




\begin{tabular}{|c|c|c|c|c|c|c|c|c|c|c|c|}
\hline Metals & S1 & S2 & S3 & S4 & S5 & S6 & S7 & S8 & S9 & S10 & Mean \\
\hline $\begin{array}{l}\text { Ash masses } \\
(\mathrm{mg})\end{array}$ & 11.10 & 9.60 & 7.10 & 15.60 & 12.90 & 23.60 & 15.60 & 10.00 & 12.10 & 21.40 & - \\
\hline $\mathrm{Cd}$ & $1.02 \pm 0.03$ & $0.50 \pm 0.09$ & $0.11 \pm 0.01$ & $0.75 \pm 0.03$ & $0.70 \pm 0.02$ & $0.96 \pm 0.04$ & $0.28 \pm 0.14$ & $0.30 \pm 0.11$ & $0.40 \pm 0.17$ & $0.58 \pm 0.14$ & 0.56 \\
\hline Co & $0.05 \pm 0.03$ & $0.04 \pm 0$ & $0.16 \pm 0.01$ & $0.17 \pm 0.13$ & $0.84 \pm 0.16$ & $0.19 \pm 011$ & $0.03 \pm 0.01$ & $0.01 \pm 0$ & $0.58 \pm 0.18$ & $0.02 \pm 0$ & 0.21 \\
\hline $\mathrm{Cr}$ & $0.66 \pm 0.26$ & $0.29 \pm 0.14$ & $1.11 \pm 0.19$ & $1.26 \pm 0.14$ & $2.04 \pm 0.20$ & $2.71 \pm 0.16$ & $0.15 \pm 0.01$ & $0.13 \pm 0.02$ & $0.28 \pm 0.11$ & $0.10 \pm 0$ & 0.87 \\
\hline $\mathrm{Cu}$ & $3.38 \pm 0.38$ & $2.38 \pm 0.23$ & $1.63 \pm 0.11$ & $2.13 \pm 0.25$ & $1.25 \pm 0.17$ & $2.25 \pm 0.25$ & $9.95 \pm 0.54$ & $2.25 \pm 0.11$ & $9.15 \pm 0.42$ & $4.43 \pm 0.27$ & 3.88 \\
\hline $\mathrm{Fe}$ & $31.25 \pm 0.50$ & $33.63 \pm 0.38$ & $34.38 \pm 0.88$ & $88.13 \pm 2.38$ & $190.00 \pm 10.00$ & $250.00 \pm 5.00$ & $571.63 \pm 10.11$ & $240.48 \pm 10.53$ & $327.70 \pm 10.14$ & $236.15 \pm 3.00$ & 200.34 \\
\hline $\mathrm{Mn}$ & $34.88 \pm 0.63$ & $38.38 \pm 0.52$ & $52.00 \pm 0.75$ & $110.50 \pm 6.25$ & $47.13 \pm 1.88$ & $64.50 \pm 0.75$ & $32.53 \pm 0.32$ & $19.60 \pm 0.28$ & $20.23 \pm 0.32$ & $24.50 \pm 0.28$ & 44.43 \\
\hline $\mathrm{Ni}$ & $1.35 \pm 0.18$ & $0.66 \pm 0.11$ & $1.49 \pm 0.19$ & $1.11 \pm 0.13$ & $1.39 \pm 0.21$ & $1.44 \pm 0.25$ & $0.90 \pm 0.12$ & $0.63 \pm 0.13$ & $2.63 \pm 0.26$ & $0.20-0.05$ & 1.18 \\
\hline $\mathrm{Pb}$ & $0.56 \pm 0.10$ & $0.43 \pm 0.15$ & $0.67 \pm 0.21$ & $0.24 \pm 0.14$ & $0.31 \pm 0.16$ & $0.71 \pm 0.25$ & $3.65 \pm 0.40$ & $2.50 \pm 0.22$ & $6.83 \pm 0.39$ & $8.08 \pm 0.55$ & 2.40 \\
\hline $\mathrm{Zn}$ & $7.24 \pm 0.16$ & $11.74 \pm 0.04$ & $8.71 \pm 0.56$ & $12.84 \pm 0.21$ & $5.83 \pm 0.20$ & $8.30 \pm 0.30$ & $19.05 \pm 1.30$ & $6.38 \pm 0.46$ & $25.83 \pm 2.56$ & $19.08 \pm 2.54$ & 12.50 \\
\hline Total & 80.39 & 88.05 & 100.26 & 217.13 & 249.49 & 331.06 & 638.17 & 272.28 & 393.63 & 293.14 & 266.36 \\
\hline
\end{tabular}

Table 2. Heavy metal concentrations ( $\left.\mathrm{mg} \mathrm{kg}^{-1} \mathrm{~d} . \mathrm{w}.\right)$ in the wood pellet ashes.

Preparation of samples. The chemical determinations of the heavy metals in wood pellet ashes (Table 2) were made by wet digestion by soaking the samples in $25 \mathrm{~mL}$ of $65 \% \mathrm{HNO}_{3}$ in polytetrafluoroethylene (PTFE) vessels. After evaporation of the nitrogen oxides, the vessels were closed and allowed to react for $14 \mathrm{~h}$ at $80^{\circ} \mathrm{C}$, following by cooling to room temperature. Then, the digest was filtered, transferred to a $25 \mathrm{~mL}$ volumetric flask, and filled up with redistilled water to the mark. All samples and blank were prepared in three replicates ${ }^{19-21}$.

Heavy metal analysis. Metal analyses in ash samples of mentioned wood pellets were performed using a flame atomic absorption spectrometry (Varian AA240FS) for $\mathrm{Mn}, \mathrm{Fe}, \mathrm{Pb}$, and $\mathrm{Zn}$ and graphite furnace (Varian AA240Z) for $\mathrm{Cd}, \mathrm{Co}, \mathrm{Cr}, \mathrm{Cu}$, and Ni. A blank probe was prepared using the same digestion method to avoid the matrix effect. Standard metal solutions used for the calibration graphs were prepared by diluting $1000 \mathrm{mg} \mathrm{L}^{-1}$ stock single-element atomic absorption standard solutions of $\mathrm{Cd}, \mathrm{Co}, \mathrm{Cr}, \mathrm{Cu}, \mathrm{Fe}, \mathrm{Mn}, \mathrm{Ni}, \mathrm{Pb}$, and $\mathrm{Zn}$ (Certipur Grade, Merck, Germany). Linear calibration graphs with correlation coefficients $>0.99$ were obtained for all analyzed metals. The accuracy of the method was evaluated using the standard reference materials: Fine Fly Ash (CTA-FFA-1, Institute of Nuclear Chemistry and Technology Poland) and Fly Ash from pulverized coal (BCR-038, Institute of reference materials and measurements-IRMM, Belgium). The obtained results were in the range of the reference materials. The detection limit (LOD) and limit of quantification (LOQ) for the nine analyzed metals were calculated based on $\mathrm{X}_{\mathrm{b}}+3 \mathrm{SD}_{\mathrm{b}}$ and $\mathrm{X}_{\mathrm{b}}+10 \mathrm{SD}_{\mathrm{b}}$, respectively, where $\mathrm{X}_{\mathrm{b}}$ is the mean concentration of the blank sample $(\mathrm{n}=8)$ and $\mathrm{SD}_{\mathrm{b}}$ is the standard deviation of the blank for eight readings $\mathrm{s}^{22}$. The values of the LOD were: $\mathrm{Cd}\left(0.61 \mu \mathrm{g} \mathrm{L}^{-1}\right)$, Co $\left(0.49 \mu \mathrm{g} \mathrm{L}^{-1}\right), \mathrm{Cr}\left(0.67 \mu \mathrm{g} \mathrm{L}^{-1}\right), \mathrm{Cu}\left(20.10 \mu \mathrm{g} \mathrm{L}^{-1}\right), \mathrm{Fe}\left(83.85 \mu \mathrm{g} \mathrm{L}^{-1}\right)$, $\mathrm{Mn}\left(6.42 \mu \mathrm{g} \mathrm{L}^{-1}\right), \mathrm{Ni}\left(1.12 \mu \mathrm{g} \mathrm{L}{ }^{-1}\right), \mathrm{Pb}\left(23.77 \mu \mathrm{g} \mathrm{L}^{-1}\right), \mathrm{Zn}\left(58.68 \mu \mathrm{g} \mathrm{L}^{-1}\right)$, and LOQ values were: Cd $\left(1.25 \mu \mathrm{g} \mathrm{L}^{-1}\right)$, Co $\left(1.41 \mu \mathrm{g} \mathrm{L}^{-1}\right), \mathrm{Cr}\left(1.42 \mu \mathrm{g} \mathrm{L}^{-1}\right)$, Cu $\left(47.66 \mu \mathrm{g} \mathrm{L}^{-1}\right), \mathrm{Fe}\left(111.2 \mu \mathrm{g} \mathrm{L}^{-1}\right), \mathrm{Mn}\left(16.14 \mu \mathrm{g} \mathrm{L}^{-1}\right), \mathrm{Ni}\left(2.70 \mu \mathrm{g} \mathrm{L}^{-1}\right), \mathrm{Pb}$ $\left(47.73 \mu \mathrm{g} \mathrm{L}^{-1}\right)$ and $\mathrm{Zn}\left(71.05 \mu \mathrm{g} \mathrm{L}^{-1}\right)$.

Pollution evaluation. The metal pollution index (MPI) as the geometric mean of the concentration of all metals found in ashes of wood samples was calculated by the following Eq. $(2)^{23}$ :

$$
\text { MPI }=\left(\mathrm{C}_{1} \cdot \mathrm{C}_{2} \cdots \mathrm{C}_{\mathrm{k}}\right)^{1 / \mathrm{k}}
$$

where $C_{1}$ is the concentration value of the first metal, $C_{2}$ is the concentration value of the second metal, $C_{k}$ is the concentration value of the kth metal.

Evaluation of the presence and the grade of anthropogenic activity were demonstrated through the calculation of the enrichment factor (EF), widely used in environmental issues ${ }^{24}$. To understand which elements were relatively enriched in the different wood pellet ash samples, the heavy metal enrichment factor was calculated relative to soil values according to Eq. $(3)^{25}$.

$$
\mathrm{EF}=\frac{\left(\frac{\mathrm{C}_{\mathrm{k}}}{\mathrm{E}_{\mathrm{ref}}}\right)_{\text {ashes }}}{\left(\frac{\mathrm{C}_{\mathrm{k}}}{\mathrm{E}_{\mathrm{ref}}}\right)_{\text {soil }}}
$$

where $C_{k}$ is the concentration of the element in the sample or the soil, $E_{\text {ref }}$ the concentration of the reference element used for normalization. A reference element is an element commonly stable in the soil characterized by the absence of vertical mobility and/or degradation phenomena. As in many studies as a reference element were Fe, $\mathrm{Al}, \mathrm{Mn}, \mathrm{Sc}$, or total organic carbon used ${ }^{26,27}$. Therefore Fe has been chosen as reference material in this study. Iron is one of the major constituents of soil, as well as the average chemical constituent of the upper continental crust ${ }^{26}$.

Health risk assessment. The general exposure equations used in this study were adapted according to the US Environmental Protection Agency guidance ${ }^{28-30}$. The daily exposure (D) to heavy metals via wood pellet ash was calculated for the three main routes of exposure: (i) direct ingestion of ash particles $\left(D_{\text {ing }}\right)$; (ii) inhalation of 
suspended particles via mouth and nose $\left(D_{\text {inh }}\right)$; and (iii) dermal absorption to skin adhered ash particles $\left(D_{\text {dermal }}\right)$. Equations (4) to (6) were used to calculate exposure via ingestion, inhalation, and dermal route, respectively ${ }^{22,31}$.

$$
\begin{gathered}
\mathrm{D}_{\text {ing }}=\mathrm{C} \cdot \frac{\mathrm{IngR} \cdot \mathrm{EF} \cdot \mathrm{ED}}{\mathrm{BW} \cdot \mathrm{AT}} \cdot \mathrm{CF} 1, \\
\mathrm{D}_{\mathrm{inh}}=\mathrm{C} \cdot \frac{\mathrm{InhR} \cdot \mathrm{EF} \cdot \mathrm{ED}}{\mathrm{PEF} \cdot \mathrm{BW} \cdot \mathrm{AT}}, \\
\mathrm{D}_{\text {dermal }}=\mathrm{C} \cdot \frac{\mathrm{SA} \cdot \mathrm{SL} \cdot \mathrm{ABS} \cdot \mathrm{EF} \cdot \mathrm{ED}}{\mathrm{BW} \cdot \mathrm{AT}} \cdot \mathrm{CF} 1,
\end{gathered}
$$

where $\mathrm{c}\left(\mathrm{mg} \mathrm{kg}^{-1}\right)$ is the heavy metals concentrations in ash samples; IngR $\left(\mathrm{mg} \mathrm{day}^{-1}\right)$ is the conservative estimates of dust ingestion rates, 50 for adults, 200 for children ${ }^{30,32}$; $\operatorname{InhR}\left(\mathrm{m}^{3} \mathrm{~h}^{-1}\right)$ is the inhalation rate, 2.15 for adults, 1.68 for children ${ }^{32}$; EF ( $\mathrm{h} \mathrm{year}^{-1}$ ) is the exposure frequency, 1225 for adults and children ${ }^{22}$; ED (years) is the exposure duration, 70 for adults, 6 for children ${ }^{22}$; BW $(\mathrm{kg})$ is the body weight, 80 for adults, 18.60 for children ${ }^{32}$; AT (days) is the averaging time, 25,550 for adults, 2190 for children ${ }^{22}$; PEF is the particle emission factor $\left(\mathrm{m}^{3} \mathrm{~kg}^{-1}\right)$, $6.80 \times 10^{8}$ for adults and children ${ }^{31}$; SA $\left(\mathrm{cm}^{3}\right)$ is the exposed skin area, 6840 for adults, 2550 for children ${ }^{32}$; SL $\left(\mathrm{mg} \mathrm{cm}^{-2}\right)$ is the skin adherence factor, 0.22 for adults, 0.27 for children ${ }^{32}$; ABS is the dermal absorption factor, 0.001 for adults and children ${ }^{31}$; CF1 is the unit conversation factor, $10^{-6}$ for adults and children ${ }^{22}$.

The potential non-carcinogenic risk for each metal was estimated using the Hazard coefficient (HQ), as suggested by US EPA ${ }^{33}$. The HQ under various routes of exposure such as ingestion $\left(\mathrm{HQ}_{\text {ing }}\right)$, inhalation $\left(\mathrm{HQ}_{\text {inh }}\right)$, and dermal $\left(\mathrm{HQ}_{\mathrm{dermal}}\right)$ was calculated as a ratio of daily exposure (D) to reference dose of each metal (RfD) according to Eq. $(7)^{32}$.

$$
\mathrm{HQ}_{\mathrm{k}}=\frac{\mathrm{D}_{\mathrm{k}}}{\mathrm{RfD}}
$$

where $\mathrm{k}$ is ingestion, inhalation, or dermal route. The total hazard index (HI) of heavy metal for all routes of exposure was calculated as a sum of $\mathrm{HQ}_{\text {ing, }}, \mathrm{HQ}_{\text {inh }}$, and $\mathrm{HQ}_{\text {dermal }}$ as given in Eq. $(8)^{34}$.

$$
\mathrm{HI}=\mathrm{HQ}_{\mathrm{ing}}+\mathrm{HQ}_{\text {inh }}+\mathrm{HQ}_{\text {dermal }} \text {. }
$$

The carcinogenic risk (Risk) for potential carcinogenic metals was calculated by multiplying the doses by the corresponding slope factor (SF), as given in Eq. (9) ${ }^{35}$. The carcinogenic oral, inhalation, and dermal SF, as well as dermal absorption toxicity values, were provided from the Integrated Risk Information System ${ }^{30}$. The reference doses for $\mathrm{Pb}$ were taken from the Guidelines for Drinking Water Quality published by the World Health Organization $^{36}$.

$$
\text { Risk }=\sum_{\mathrm{k}=1}^{\mathrm{n}} \mathrm{D}_{\mathrm{k}} \cdot \mathrm{SF}_{\mathrm{k}},
$$

where SF is the cancer slope factor for individually metal and $\mathrm{k}$ route of exposure (ingestion, inhalation, or dermal path). The total cancer risk (Risk total $_{\text {) }}$ of potential carcinogens was calculated as the sum of the individual risk values using the following Eq. (10).

$$
\text { Risk }_{\text {total }}=\text { Risk }_{\text {ing }}+\text { Risk }_{\text {inh }}+\text { Risk }_{\text {dermal }} .
$$

\section{Results and discussions}

Concentration of heavy metals in the ashes of wood pellets. The content of heavy metals in wood pellet ash produced by biomass combustion depends on several factors: the type and quality of wood biomass, the production process, the use of additives, the characteristics of the furnace, the temperature of the process, etc. The results of the heavy metal contents in the wood pellet ash samples represent the mean values of three replicate determination and are given in Table 2. The total concentrations of nine (9) tested metals were expressed as the sum of the metal concentrations in the ash for ten (10) collected wood pellet samples. The total heavy metal concentrations ranged from $80.39 \mathrm{mg} \mathrm{kg}^{-1}$ (S1) to $638.17 \mathrm{mg} \mathrm{kg}^{-1}$ (S7). The mean concentrations of analyzed heavy metals decrease as follows $\mathrm{Fe}>\mathrm{Mn}>\mathrm{Zn}>\mathrm{Cu}>\mathrm{Pb}>\mathrm{Ni}>\mathrm{Cr}>\mathrm{Cd}>\mathrm{Co}$.

For comparison, the literature values of heavy metal concentrations in wood ash and ash of different wood biomass regarding the extraction procedure are presented in Table 3. The total heavy metal contents obtained after $\mathrm{HNO}_{3}$ extraction of wood samples are comparable to the results presented by other authors, especially for $\mathrm{Cd}, \mathrm{Cu}$, and $\mathrm{Pb}^{13,37}$. Considerable higher concentrations of $\mathrm{Cr}, \mathrm{Cu}, \mathrm{Ni}$, and $\mathrm{Zn}$ in ash were found by Eberhardt and $\mathrm{Pan}^{14}$. However, because of various sample preparation methods used, different wood composition, and dissimilar combustion methods used, the studied ash shows variety in the heavy metal contents. This diversity in chemical composition is crucial in the finding of possible ways of utilizing ash for dispersion into the soil or use for other purposes ${ }^{5,38}$. European legislation of the ash utilization in forestry and agriculture is diverse in different countries. In all analyzed samples, metal concentrations are lower than the limit values for some European countries such as Germany, Sweden, and Denmark ${ }^{39}$.

Additionally, a more comprehensive comparison in the meaning of detailed differences between the minimum and maximum values of heavy metals were compared to similar investigations considering the combination of 


\begin{tabular}{|l|l|l|l|l|l|l|l|l|l|}
\hline $\begin{array}{l}\text { Methods of } \\
\text { extraction }\end{array}$ & Cd & Co & Cr & Cu & Mn & Ni & Pb & Zn & References \\
\hline $\begin{array}{l}\mathrm{HNO}_{3} \text { and } \mathrm{HCl} \\
(3: 1)\end{array}$ & $<0.30$ & 2.50 & 15 & $<10$ & - & 19 & $<3$ & 160 & 13 \\
\hline $\begin{array}{l}\mathrm{HNO}_{3} \text { and } \mathrm{HCl} \\
(1: 3)\end{array}$ & 4.39 & 0.50 & 38.50 & 37.20 & - & 47.30 & 11.80 & 345 & 14 \\
\hline $\mathrm{HNO}_{3}$ & 4.54 & 0.70 & 37.50 & 37.80 & - & 47.50 & 12.90 & 357 & 14 \\
\hline- & $0.40-0.70$ & $0-7$ & $>60$ & $15-300$ & $2-5.50$ & $40-250$ & $15-60$ & $15-103$ & 37 \\
\hline $\mathrm{HNO}_{3}$ & $0.11-1.02$ & $0.01-0.84$ & $0.10-2.71$ & $1.5-9.95$ & $19.60-110.50$ & $0.20-2.63$ & $0.24-8.08$ & $5.83-19.08$ & This study \\
\hline
\end{tabular}

Table 3. The total heavy metal concentration $\left(\mathrm{mg} \mathrm{kg}^{-1}\right)$ in wood ash by different authors regarding the method of extraction. "-" no data; bottom ash of wood chips, sawdust, bark, and peat ${ }^{13}$; flay ash of wood chips $^{14}$; bottom wood ash $^{37}$; bottom wood pellet ash (this study).

\begin{tabular}{|c|c|c|c|c|c|c|c|}
\hline \multirow[b]{2}{*}{ Origin/type } & \multirow[b]{2}{*}{ Ash (\%) } & \multicolumn{5}{|c|}{ Concentration $\mathrm{mg} \mathrm{kg}^{-1}$} & \multirow[b]{2}{*}{ References } \\
\hline & & Value & Cd & Co & $\mathrm{Cr}$ & $\mathrm{Cu}$ & \\
\hline \multirow{2}{*}{- loak } & \multirow{2}{*}{2.21} & Min & 5.92 & \multirow{2}{*}{-} & 22.41 & 304.0 & \multirow{2}{*}{8} \\
\hline & & Max & 8.26 & & 34.92 & 307.0 & \\
\hline \multirow{2}{*}{ Lublin/beech, hornbeam } & \multirow{2}{*}{10.18} & Min & - & \multirow{2}{*}{-} & 12.49 & 25.21 & \multirow{2}{*}{40} \\
\hline & & Max & & & 20.65 & 104.00 & \\
\hline \multirow{2}{*}{ Italy/beech, conifers } & \multirow{2}{*}{$<0.70$} & Min & 0.08 & \multirow{2}{*}{-} & 0.46 & 2.20 & \multirow{2}{*}{25} \\
\hline & & $\max$ & 1.00 & & 2.20 & 4.40 & \\
\hline \multirow{2}{*}{ Canada/fir } & \multirow{2}{*}{$<0.40$} & Min & 0.08 & & 0.93 & 4.60 & \multirow{2}{*}{25} \\
\hline & & Max & 0.10 & & 3.40 & 8.50 & \\
\hline Finland/- & & Mean & - & - & - & 23 & 41 \\
\hline \multirow{2}{*}{ B\&H/beech, fir, oak, hornbeam, spruce } & \multirow{2}{*}{1.47} & Min & 0.11 & 0.01 & 0.10 & 1.25 & \multirow{2}{*}{ This study } \\
\hline & & Max & 1.02 & 0.84 & 2.71 & 9.95 & \\
\hline
\end{tabular}

Table 4. Comparison of obtained values of heavy metals $(\mathrm{Cd}, \mathrm{Co}, \mathrm{Cr}$, and $\mathrm{Cu})$ in analyzed wood pellets with similar studies.

\begin{tabular}{|c|c|c|c|c|c|c|c|c|}
\hline \multirow[b]{2}{*}{ Origin/type } & \multirow[b]{2}{*}{ Ash (\%) } & \multicolumn{6}{|c|}{ Concentration $\mathrm{mg} \mathrm{kg}^{-1}$} & \multirow[b]{2}{*}{ References } \\
\hline & & \begin{tabular}{|l|} 
Value \\
\end{tabular} & $\mathrm{Fe}$ & Mn & $\mathbf{N i}$ & $\mathbf{P b}$ & Zn & \\
\hline \multirow{2}{*}{- loak } & \multirow{2}{*}{2.21} & Min & 4271 & - & 16.40 & 9.36 & 616.67 & \multirow{2}{*}{40} \\
\hline & & Max & 5390 & & 16.82 & 9.69 & 716.00 & \\
\hline \multirow{2}{*}{ Lublin/beech, hornbeam } & \multirow{2}{*}{10.18} & Min & 1088 & 313.33 & 68.57 & 9.08 & 68.83 & \multirow[t]{2}{*}{8} \\
\hline & & Max & 4560 & 482.67 & 99.07 & 11.23 & 160.33 & \\
\hline \multirow{2}{*}{ Italy/beech, conifers } & \multirow{2}{*}{$<0.70$} & Min & 119.00 & 60.00 & 0.33 & 0.23 & 2.30 & \multirow{2}{*}{25} \\
\hline & & $\max$ & 377.00 & 68.00 & 2.60 & 0.70 & 7.80 & \\
\hline \multirow{2}{*}{ Canada/fir } & \multirow{2}{*}{$<0.40$} & Min & 83.00 & 68.00 & 0.18 & 0.51 & 6.70 & \multirow{2}{*}{25} \\
\hline & & Max & 247.00 & 70.00 & 1.50 & 0.56 & 10.0 & \\
\hline Finland/- & & Mean & - & 1370 & - & - & 350 & 41 \\
\hline \multirow{2}{*}{$\begin{array}{l}\text { Bosnia and Herzegovina/beech, fir, oak, hornbeam, } \\
\text { spruce }\end{array}$} & \multirow{2}{*}{1.47} & Min & 31.25 & 19.60 & 0.20 & 0.24 & 5.83 & \multirow{2}{*}{ This study } \\
\hline & & Max & 571.63 & 110.50 & 1.49 & 8.08 & 25.83 & \\
\hline
\end{tabular}

Table 5. Comparison of obtained values of heavy metals ( $\mathrm{Fe}, \mathrm{Mn}, \mathrm{Ni}, \mathrm{Pb}$, and $\mathrm{Zn}$ ) in analyzed pellets with similar studies.

biomass (same or similar origin) and the same combustion temperature to ashes $\left(500-600{ }^{\circ} \mathrm{C}\right)$ are shown in Tables 4 and 5. Analyzing the results from Tables 4 and 5, it could be concluded that the ash contribution of the studied biomass used often in $\mathrm{B} \& \mathrm{H}$ is very low, which is typical for given raw material.

Generally, the ash content for wood is often less than $2 \%{ }^{42}$. However, under incomplete combustion due to unburnt organic material, high values of ash content could be obtained, etc. In the case of biomass from Lublin ${ }^{8}$. Sampling site, harvesting time as well as harvest conditions are significant factors that contribute to the ash content of biomass.

Regarding the heavy metal content in the studied biomass, it could be concluded that the results varied within very wide limits. The highest value for $\mathrm{Cd}, \mathrm{Cr}, \mathrm{Cu}, \mathrm{Fe}$, and $\mathrm{Zn}$ was found in the ash biomass of oak, for which the highest content of ash was also recorded ${ }^{40}$. Except for oak ash, high values for $\mathrm{Cd}, \mathrm{Cr}, \mathrm{Cu}$, and Fe were also 


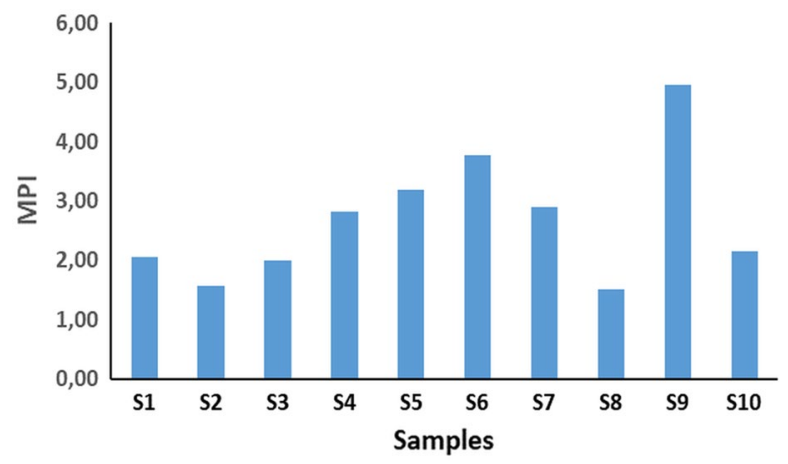

Figure 1. MPI values of analyzed wood pellet ashes.

\begin{tabular}{|c|c|c|c|c|c|c|c|c|c|c|c|}
\hline Metals & S1 & S2 & S3 & S4 & S5 & S6 & S7 & S8 & S9 & S10 & Mean \\
\hline $\mathrm{Mn}$ & 59.37 & 60.7 & 80.45 & 66.7 & 13.19 & 13.72 & 3.04 & 4.30 & 3.29 & 5.53 & 31.03 \\
\hline $\mathrm{Ni}$ & 18.46 & 8.39 & 18.52 & 5.38 & 3.12 & 2.46 & 0.67 & 1.12 & 3.42 & 0.36 & 6.19 \\
\hline Co & 2.05 & 1.52 & 5.96 & 2.46 & 5.66 & 0.97 & 0.07 & 0.02 & 2.26 & 0.05 & 2.10 \\
\hline $\mathrm{Cd}$ & 5216 & 2378.82 & 535.19 & 1361.62 & 589.47 & 614.4 & 78.37 & 199.60 & 195.30 & 392.97 & 1156.17 \\
\hline $\mathrm{Pb}$ & 28.64 & 20.45 & 31.18 & 4.35 & 2.61 & 4.54 & 10.22 & 16.63 & 33.35 & 54.74 & 20.67 \\
\hline $\mathrm{Zn}$ & 104.5 & 157.25 & 114.12 & 65.63 & 13.82 & 14.95 & 15.01 & 11.95 & 35.51 & 36.39 & 56.91 \\
\hline $\mathrm{Cu}$ & 138.54 & 90.61 & 60.71 & 30.95 & 8.42 & 11.52 & 22.28 & 11.98 & 35.74 & 24.01 & 43.48 \\
\hline $\mathrm{Cr}$ & 7.94 & 3.24 & 12.14 & 5.38 & 4.03 & 4.08 & 0.10 & 0.20 & 0.32 & 0.16 & 3.76 \\
\hline
\end{tabular}

Table 6. Enrichment factors for analyzed samples.

recorded for the ash of beech and hornbeam wood type ${ }^{8}$. Furthermore, the highest content of $\mathrm{Mn}, \mathrm{Ni}$, and $\mathrm{Pb}$ was also obtained for beech and hornbeam wood type $\mathrm{e}^{8}$, while for $\mathrm{Zn}$, the value corresponds to the wood pellet ash originating from a grate-fired boiler at a small-scale, heating plant at Kuusamo, Eastern Finland ${ }^{41}$. Differences between particular types of organic material, regarding the chemical composition, vary significantly due to different factors i.e.: tree species, growing site, climate and tree component (bark, wood, and leaves), age of the tree, etc. However, detailed analyses and further monitoring of biomass are needed due to insufficient data about the content of hazardous elements in it. The presented results were furthermore compared with the limit value (forest fertilizer) for wood, peat, and biomass-derived ashes used as forest fertilizer to conclude the possible use of such ashes. The limit value of $17.5 ; 700 ; 150 ; 300 ; 4500$; and $150 \mathrm{mg} \mathrm{kg}^{-1}$ for $\mathrm{Cd}, \mathrm{Cu}, \mathrm{Pb}, \mathrm{Cr}, \mathrm{Zn}$, and Ni is stated as maximal allowable heavy metal concentrations in forest fertilizer ${ }^{43}$. We compared obtained results of heavy metals in ash samples with the limit values given by EU directives and regulations ${ }^{43}$. All analyzed samples have metal concentrations lower than the limit values.

Metal pollution index. In addition to the above, to compare the total metal content in analyzed ash samples the MPI was used. MPI is an important and precise way of monitoring metal pollution levels in different contaminated mediums ${ }^{44}$. The obtained results for MPI are presented in Fig. 1. The MPI values in this study ranged from 1.51 to 4.96. The highest MPI value was measured for Sample 9 (beech, spruce, fir), while the lowest one for Sample 8 (beech, spruce). Higher MPI of analyzed samples reflects heavy metal richness in wood pellet ashes, which can cause the accumulation of heavy metals in the soil during ash disposal. Comparing the results of MPI presented in Fig. 1 with a similar study for wood pellet ash from Italy ${ }^{25}$, it could be concluded that the MPI values in this study were lower. Therefore, it could be mentioned that the pollution with heavy metals by using wood pellets described in this work would be less significant than those when using wood pellet samples from Italy as an energy source.

Enrichment factor (EF). Moreover, the EF was used to value the effect of the possible addition of wood pellet ashes to soils. An important condition for the maintainable use of ashes in agriculture is the assessment of possible environmental impacts. Numerical values of EF indicate different levels of pollution. Values of $\mathrm{EF}<2$ suggest the matrices can be classified as a deficiency to minimal enrichment. While, a $2<\mathrm{EF}<5$ indicates moderate enrichment, $5<\mathrm{EF}<20$ significant enrichments, $20<\mathrm{EF}<40$ very high enrichment and $\mathrm{EF}>40$ extremely high enrichment ${ }^{45}$. Enrichment factors obtained for analyzed samples have values from 0.97 for Co (S6) to 5216 for $\mathrm{Cd}$ (S1) (Table 6). The mean EF values for $\mathrm{Mn}, \mathrm{Cd}, \mathrm{Pb}, \mathrm{Zn}$, and $\mathrm{Cu}$ are significantly higher than 10 , for $\mathrm{Co}$ and $\mathrm{Cr}$ less than 10, while for $\mathrm{Ni}$ it is close to 10. EFs much higher than 10 are considered to initiate primarily originated from anthropogenic sources. Therefore, the metal content in the analyzed wood pellet ash indicates that it is a serious contaminant of soil and the environment. 


\begin{tabular}{|c|c|c|c|c|c|c|c|c|c|c|c|}
\hline \multirow[b]{2}{*}{ Metal } & \multicolumn{3}{|c|}{ RfD (mg kg ${ }^{-1}$ per day) } & \multicolumn{4}{|l|}{ Children } & \multicolumn{4}{|l|}{ Adults } \\
\hline & Ing & Inhal & Dermal & $H_{Q_{\text {ing }}}$ & $H Q_{\text {inh }}$ & $\mathbf{H Q}_{\text {der }}$ & HI & $\mathbf{H Q}_{\text {ing }}$ & $H_{\text {inh }}$ & $\mathbf{H Q}_{\text {der }}$ & HI \\
\hline $\mathrm{Mn}$ & $1.40 \mathrm{E}-02$ & - & - & $1.15 \mathrm{E}-01$ & - & - & $1.15 \mathrm{E}-01$ & $6.66 \mathrm{E}-03$ & - & - & $6.66 \mathrm{E}-03$ \\
\hline $\mathrm{Ni}$ & $2.00 \mathrm{E}-02$ & $2.00 \mathrm{E}-03$ & $5.40 \mathrm{E}-03$ & $2.13 \mathrm{E}-03$ & $2.63 \mathrm{E}-07$ & $2.71 \mathrm{E}-05$ & $2.16 \mathrm{E}-03$ & $1.24 \mathrm{E}-04$ & 7.83E-08 & $1.38 \mathrm{E}-05$ & $1.38 \mathrm{E}-04$ \\
\hline Co & $2.00 \mathrm{E}-02$ & $3.00 \mathrm{E}-05$ & $1.60 \mathrm{E}-02$ & 3.77E-04 & $3.11 \mathrm{E}-06$ & $1.62 \mathrm{E}-06$ & $3.64 \mathrm{E}-02$ & $2.19 \mathrm{E}-05$ & $9.24 \mathrm{E}-07$ & $8.25 \mathrm{E}-07$ & $2.36 \mathrm{E}-05$ \\
\hline $\mathrm{Cd}$ & $1.00 \mathrm{E}-03$ & $1.00 \mathrm{E}-03$ & $1.00 \mathrm{E}-05$ & $2.02 \mathrm{E}-02$ & $2.50 \mathrm{E}-07$ & $6.96 \mathrm{E}-03$ & $2.72 \mathrm{E}-02$ & $1.18 \mathrm{E}-03$ & 7.43E-08 & $3.54 \mathrm{E}-03$ & $4.72 \mathrm{E}-03$ \\
\hline $\mathrm{Pb}$ & $3.50 \mathrm{E}-03$ & $3.00 \mathrm{E}-03$ & $5.25 \mathrm{E}-04$ & $2.47 \mathrm{E}-02$ & $3.56 \mathrm{E}-07$ & 5.67E-04 & $2.53 \mathrm{E}-02$ & $1.44 \mathrm{E}-03$ & $1.06 \mathrm{E}-07$ & $2.88 \mathrm{E}-04$ & $1.73 \mathrm{E}-03$ \\
\hline $\mathrm{Zn}$ & $3.00 \mathrm{E}-01$ & $3.00 \mathrm{E}-01$ & $6.00 \mathrm{E}-02$ & $1.50 \mathrm{E}-03$ & $1.86 \mathrm{E}-08$ & $2.59 \mathrm{E}-05$ & $1.53 \mathrm{E}-03$ & $8.74 \mathrm{E}-05$ & 5.53E-09 & $1.32 \mathrm{E}-05$ & $1.01 \mathrm{E}-04$ \\
\hline $\mathrm{Cu}$ & $4.00 \mathrm{E}-02$ & $4.00 \mathrm{E}-01$ & $1.20 \mathrm{E}-02$ & $3.50 \mathrm{E}-03$ & $4.32 \mathrm{E}-09$ & $4.02 \mathrm{E}-05$ & $3.54 \mathrm{E}-03$ & $2.03 \mathrm{E}-04$ & $1.29 \mathrm{E}-09$ & $2.04 \mathrm{E}-05$ & $2.23 \mathrm{E}-04$ \\
\hline $\mathrm{Cr}$ & $3.00 \mathrm{E}-03$ & $2.00 \mathrm{E}-04$ & \begin{tabular}{|l|}
$6.00 \mathrm{E}-05$ \\
\end{tabular} & $1.05 \mathrm{E}-02$ & $1.95 \mathrm{E}-06$ & $1.81 \mathrm{E}-03$ & $1.23 \mathrm{E}-02$ & \begin{tabular}{|l|}
$6.10 \mathrm{E}-04$ \\
\end{tabular} & 5.79E-07 & 9.19E-04 & $1.53 \mathrm{E}-03$ \\
\hline$\Sigma$ & - & - & - & $1.78 \mathrm{E}-01$ & 5.95E-06 & $9.43 \mathrm{E}-03$ & $2.23 \mathrm{E}-01$ & \begin{tabular}{|l|}
$1.03 \mathrm{E}-02$ \\
\end{tabular} & $1.77 \mathrm{E}-06$ & $4.80 \mathrm{E}-03$ & $1.51 \mathrm{E}-02$ \\
\hline
\end{tabular}

Table 7. The reference doses, hazard coefficient, and non-carcinogenic hazard index for children and adults.

\begin{tabular}{|c|c|c|c|c|c|c|c|c|}
\hline \multirow[b]{2}{*}{ Element } & \multirow[b]{2}{*}{$\mathrm{SF}_{\text {ing }}$} & \multirow[b]{2}{*}{$\mathrm{SF}_{\mathrm{inh}}$} & \multicolumn{3}{|l|}{ Children } & \multicolumn{3}{|l|}{ Adults } \\
\hline & & & Risk $_{\text {ing }}$ & Risk $_{\text {inh }}$ & Risk $_{\text {total }}$ & Risk $_{\text {ing }}$ & Risk $_{\text {inh }}$ & Risk $_{\text {total }}$ \\
\hline $\mathrm{Ni}$ & 0.91 & $8.40 \mathrm{E}-01$ & $2.88 \mathrm{E}-05$ & $4.42 \mathrm{E}-10$ & $2.88 \mathrm{E}-05$ & $2.25 \mathrm{E}-06$ & $1.31 \mathrm{E}-10$ & $2.25 \mathrm{E}-06$ \\
\hline Co & - & $9.80 \mathrm{E}+00$ & - & $9.13 \mathrm{E}-10$ & $9.13 \mathrm{E}-10$ & - & $2.72 \mathrm{E}-10$ & $2.72 \mathrm{E}-10$ \\
\hline $\mathrm{Cd}$ & - & $6.30 \mathrm{E}+00$ & - & 1.57E-09 & $1.57 \mathrm{E}-09$ & - & $4.68 \mathrm{E}-10$ & $4.68 \mathrm{E}-10$ \\
\hline $\mathrm{Pb}$ & $8.50 \mathrm{E}-03$ & $4.20 \mathrm{E}-02$ & $7.36 \mathrm{E}-07$ & $4.49 \mathrm{E}-11$ & 7.36E-07 & $4.28 \mathrm{E}-08$ & $1.34 \mathrm{E}-11$ & $4.28 \mathrm{E}-08$ \\
\hline $\mathrm{Cr}$ & $5.00 \mathrm{E}-01$ & $4.10 \mathrm{E}+01$ & $1.58 \mathrm{E}-05$ & $1.60 \mathrm{E}-08$ & $1.58 \mathrm{E}-05$ & $9.16 \mathrm{E}-07$ & $4.75 \mathrm{E}-09$ & 9.21E-07 \\
\hline$\Sigma$ & - & - & $4.53 \mathrm{E}-05$ & $1.90 \mathrm{E}-08$ & $4.54 \mathrm{E}-05$ & $3.21 \mathrm{E}-06$ & $5.63 \mathrm{E}-09$ & $3.21 \mathrm{E}-06$ \\
\hline
\end{tabular}

Table 8. The cancer slope and Risk factors calculated for children and adults.

Non-carcinogenic and carcinogenic hazards for the ash samples. To assess the impact of heavy metals in wood pellet ashes on children and adults' health or the environment in general Hazard Index HI for non-cancerogenic substances and Risk index for cancerogenic substances was used. The obtained results for HI are presented in Table 7. The calculation was realized for exposure pathways by ingestion, inhalation, and dermal contact. For children, obtained results showed that the total hazard index HI for non-carcinogenic substances was 2.23E-01. Regarding total non-carcinogenic risk for children, it has a value less than $1(\mathrm{HI}<1)$, which indicates that there is a very low non-carcinogenic risk for heavy metals in the ash formed by the burning of wood pellets. The highest value for HI was obtained for the ingestion pathway (1.78E-01). Therefore, the ingestion pathway represents the highest risk, followed by dermal contact (9.43E-03), while the inhalation pathway represents the lowest risk (5.95E-06). The contribution of elements to the total $\mathrm{HI}$ value for children decrease in the following order: $\mathrm{Mn}>\mathrm{Co}>\mathrm{Cd}>\mathrm{Pb}>\mathrm{Cr}>\mathrm{Cu}>\mathrm{Ni}>\mathrm{Zn}$. The highest values obtained for $\mathrm{Mn}$, $\mathrm{Co}$, and $\mathrm{Cd}$ are similar to the previous study of wood pellet ashes ${ }^{25}$. For adults, the total HI was $1.51 \mathrm{E}-02$. The results were similar to those obtained for children, as the dominant exposure pathway was ingestion (1.03E-02). The values for dermal contact were lower (4.80E-03), and very low for inhalation (1.77E-06).

The carcinogenic risk to human health through exposure to heavy metals from wood pellet ashes was calculated for both children and adults as summarized in Table 8 . If the Risk index is in the range from $1 \times 10 \mathrm{E}-06$ to $1 \times 10 \mathrm{E}-04$ the values were acceptable or tolerable for regulatory purposes ${ }^{35}$. The total Risk index calculated for exposure of children and adults to heavy metals from ash was $4.54 \mathrm{E}-05$ and $3.21 \mathrm{E}-06$, respectively (Table 8). Obtained results for total Risk index were lower than $1 \times 10 \mathrm{E}-04$ and they are generally considered acceptable for children and adults. Therefore, the carcinogenic risk caused by $\mathrm{Ni}, \mathrm{Co}, \mathrm{Cd}, \mathrm{Pb}$, and $\mathrm{Cr}$ in the ash could be negligible. Similar to HI values total Risk index values for children were also higher related to the values for adults, these results indicate that risk related to exposure to potentially polluted wood pellet ashes are higher for children than for adults.

\section{Conclusion}

This research has exposed the quantitative analysis of heavy metals in ten wood pellet ash samples. The health implications of these metals in the ash samples studied have also been identified. The results showed that the average concentrations of the heavy metals in the wood pellet ashes varied and decreased in the order $\mathrm{Fe}>\mathrm{M}$ $\mathrm{n}>\mathrm{Zn}>\mathrm{Cu}>\mathrm{Pb}>\mathrm{Ni}>\mathrm{Cr}>\mathrm{Cd}>\mathrm{Co}$. Heavy metal content of ash from wood pellets is a significant feature that allows an assessment of the behavior of these metals in the process of combustion and use of ash. The obtained concentration values of the analyzed metals are below the limits given by the law of individual European countries (European limit values).

The addition of ash to the soil is recommended to improve the chemical, physical and biological properties of the soil in agricultural production. However, values for MPI and EF indicate that long-term disposal of wood 
pellet ash can lead to soil contamination. Although this is the first study in $\mathrm{B} \& \mathrm{H}$, the results obtained in this paper can serve as a basis for further monitoring. Hazard index (HI) for children and adults was lower than the safe limit indicating that there was no direct health risk from heavy metals from wood pellet ashes. Obtained results for the total risk index were lower than the limit value and they are generally considered acceptable for children and adults. Therefore, the carcinogenic risk caused by heavy metals in the ash could be negligible. In a view of all the metals, the results indicate that there is a low cancer risk. This study also has some limitations associated with the limited number of analyzed wood pellet samples, and our results are obtained on the laboratory production of ashes and may show some differences with those produced in home furnaces. The inclusion of a larger sample and survey data on the actual exposure to ashes from wood biomass is recommended.

\section{Data availability}

The data sets generated and/or analyzed during the current study are available from the corresponding author on reasonable request.

Received: 29 April 2021; Accepted: 4 August 2021

Published online: 09 September 2021

\section{References}

1. Pradhan, P., Mahajani, S. M. \& Arora, A. Production and utilization of fuel pellets from biomass: A review. FPT. 181, $215-232$. https://doi.org/10.1016/j.fuproc.2018.09.021 (2018).

2. García, R., González-Vázquez, M. P., Martín, A. J., Pevida, C. \& Rubiera, F. Pelletization of torrefied biomass with solid and liquid bio-additives. Renew. Energy. 151, 175-183. https://doi.org/10.1016/j.renene.2019.11.004 (2020).

3. Nunes, L. J., Godina, R., Matias, J. C. \& Catalão, J. P. Economic and environmental benefits of using textile waste for the production of thermal energy. J. Clean. Prod. 171, 1353-1360. https://doi.org/10.1016/j.jclepro.2017.10.154 (2018).

4. Bogush, A. A., Stegemann, J. A., Williams, R. \& Wood, I. G. Element speciation in UK biomass power plant residues based on composition, mineralogy, microstructure and leaching. Fuel 211, 712-725. https://doi.org/10.1016/j.fuel.2017.09.103 (2018).

5. Vassilev, S. V., Baxter, D., Andersen, L. K. \& Vassileva, C. G. An overview of the composition and application of biomass ash: Part 2. Potential utilisation, technological and ecological advantages and challenges. Fuel 105, 19-39 (2013).

6. Ribeiro, J. P., Tarelho, L. \& Gomes, A. P. Incorporation of biomass fly ash and biological sludge in the soil: Effects along the soil profile and in the leachate water. J. Soils Sediments. 18, 2023-2031. https://doi.org/10.1007/s11368-018-1949-8 (2018).

7. Sheeba, S. \& Theresa, K. Influence of fly ash, organic manures and inorganic fertilizers on nutrient uptake of rice. Int. J. Curr. Microbiol. Appl. Sci. 9, 2014-2023 (2020).

8. Zając, G., Szyszlak-Bargłowicz, J., Gołębiowski, W. \& Szczepanik, M. Chemical characteristics of biomass ashes. Energies 11, 2885. https://doi.org/10.3390/en11112885 (2018).

9. Yang, Q. et al. A review of soil heavy metal pollution from industrial and agricultural regions in China: Pollution and risk assessment. Sci. Total Environ. 642, 690-700. https://doi.org/10.1016/j.scitotenv.2018.06.068 (2018).

10. Engwa, G. A., Ferdinand, P. U., Nwalo, F. N. \& Unachukwu, M. N. Mechanism and health effects of heavy metal toxicity in humans. In Poisoning in the Modern World (eds Karcioglu, O. \& Arslan, B.) 77-87 (IntcehOpen, 2019).

11. Paithankar, J. G., Saini, S., Dwivedi, S., Sharma, A. \& Chowdhuri, D. K. Heavy metal associated health hazards: An interplay of oxidative stress and signal transduction. Chemosphere 262, 128350. https://doi.org/10.1016/j.chemosphere.2020.128350 (2021).

12. Kinuthia, G. K. et al. Levels of heavy metals in wastewater and soil samples from open drainage channels in Nairobi, Kenya: Community health implication. Sci. Rep. 10, 1-13. https://doi.org/10.1038/s41598-020-65359-5 (2020).

13. Dahl, O., Nurmesniemi, H., Pöykiö, R. \& Watkins, G. Comparison of the characteristics of bottom ash and fly ash from a mediumsize (32 MW) municipal district heating plant incinerating forest residues and peat in a fluidized-bed boiler. Fuel Process. Technol. 90, 871-878. https://doi.org/10.1016/j.fuproc.2009.04.013 (2009).

14. Eberhardt, T. L. \& Pan, H. Analysis of the fly ash from the processing of wood chips in a pilot-scale downdraft gasifier: Comparison of inorganic constituents determined by PIXE and ICP-AES. Biomass Bioenergy. 51, 163-168. https://doi.org/10.1016/j.biombioe. 2013.01.020 (2013).

15. Huremović, J. et al. Analysis of PM10, Pb, Cd, and Ni atmospheric concentrations during domestic heating season in Sarajevo, Bosnia and Herzegovina, from 2010 to 2019. Air. Qual. Atmos. Health. 13, 965-976. https://doi.org/10.1007/s11869-020-00852-4 (2020).

16. Šukalić, A. et al. Human health risk assessment of heavy metals from the agricultural soil in South Herzegovina. Agric. Conspec. Sci. 83, 45-50 (2018).

17. Delibašić, Š et al. Health risk assessment of heavy metal contamination in street dust of federation of Bosnia and Herzegovina. Hum Ecol. Risk. Assess https://doi.org/10.1080/10807039.2020.1826290 (2020).

18. Pan, H. \& Eberhardt, T. L. Characterization of the fly ash from the gasification of wood and assessment for its application as a soil amendment. BioResources 6, 3987-4004 (2011).

19. Madjar, R. M., Moț, A., Vasile Scăețeanu, G. \& Mihalache, M. Methods used for heavy metal determination in agricultural inputs. Res. J. Agric. Sci. 52, 148-158 (2020).

20. Abegunde, S. M., Oyebanji, A. O. \& Osibanjo, O. Evaluation of digestion procedures on heavy metals in soil of a dumpsite in Ibadan, South-western Nigeria. Suan Sunandha Sci. Technol. J. 5, 1-5. https://doi.org/10.14456/ssstj.2018.6 (2018).

21. Alsehli, B. R. Evaluation and comparison between a conventional acid digestion method and a microwave digestion system for heavy metals determination in mentha samples by ICP-MS. Egypt. J. Chem. 64, 869-881. https://doi.org/10.21608/EJCHEM.2020. 43322.2874 (2021).

22. Kicińska, A. Chemical and mineral composition of fly ashes from home furnaces, and health and environmental risk related to their presence in the environment. Chemosphere 215, 574-585. https://doi.org/10.1016/j.chemosphere.2018.10.061 (2019).

23. Khan, M. S., Javed, M., Rehman, M. T., Urooj, M. \& Ahmad, M. I. Heavy metal pollution and risk assessment by the battery of toxicity tests. Sci. Rep. 10, 1-10. https://doi.org/10.1038/41598-020-73468-4 (2020).

24. Looi, L. J., Aris, A. Z., Yusoff, F. M., Isa, N. M. \& Haris, H. Application of enrichment factor, geoaccumulation index, and ecological risk index in assessing the elemental pollution status of surface sediments. Environ. Geochem. Health. 41, 27-42. https://doi.org/ 10.1007/s10653-018-0149-1 (2019)

25. Orecchio, S., Amorello, D. \& Barreca, S. II) Wood pellets for home heating can be considered environmentally friendly fuels? Heavy metals determination by inductively coupled plasma-optical emission spectrometry (ICP-OES) in their ashes and the health risk assessment for the operators. Microchem. J. 127, 178-183. https://doi.org/10.1016/j.microc.2016.03.008 (2016).

26. Adeniran, J. A., Yusuf, R. O. \& Olajire, A. A. Exposure to coarse and fine particulate matter at and around major intra-urban traffic intersections of Ilorin metropolis, Nigeria. Atmos. Environ. 166, 383-392. https://doi.org/10.1016/j.atmosenv.2017.07.041 (2017). 
27. Ustaoğlu, F. \& Islam, M. S. Potential toxic elements in sediment of some rivers at Giresun, Northeast Turkey: A preliminary assessment for ecotoxicological status and health risk. Ecol. Indic. 113, 106237. https://doi.org/10.1016/j.ecolind.2020.106237 (2020).

28. USEPA. Soil screening guidance: Technical background document (1996). (Accessed 22 December 2020); https://nepis.epa.gov/ Exe/ZyPDF.cgi/100025LM.PDF?Dockey=100025LM.PDF

29. USEPA. Exposure factors handbook. Office of Research and Development (1997). (Accessed 22 December 2020); https://www. epa.gov/home/pdf-files

30. USEPA. Integrated Risk Information System (IRIS) (2005). (Accessed 22 December 2020); http://www.epa.gov/iris

31. De Miguel, E., Iribarren, I., Chacon, E., Ordonez, A. \& Charlesworth, S. Riskbased evaluation of the exposure of children to trace elements in playgrounds in Madrid (Spain). Chemosphere 66, 505-513. https://doi.org/10.1016/j.chemosphere.2006.05.065 (2007).

32. USEPA. Exposure Factors Handbook 2011 Edition (Final Report) (2011). (Accessed 22 December 2020); https://cfpub.epa.gov/ ncea/risk/recordisplay.cfm?deid=236252

33. USEPA. Risk Assessment Guidance for Superfund, Volume I: Human Health Evaluation Manual (Part A) (1989). (Accessed 22 December 2020); https://www.epa.gov/sites/production/files/2015-09/documents/rags_a.pdf

34. Mondal, P. et al. Health risk and geochemical assessment of trace elements in surface sediment along the Hooghly (Ganges) River Estuary (India). Water 13, 110. https://doi.org/10.3390/w13020110 (2021).

35. Zhang, R., Chen, T., Zhang, Y., Hou, Y. \& Chang, Q. Health risk assessment of heavy metals in agricultural soils and identification of main influencing factors in a typical industrial park in northwest China. Chemosphere 252, 126591. https://doi.org/10.1016/j. chemosphere.2020.126591 (2020).

36. WHO (World Health Organization). Water, Sanitation and Health Team. Guidelines for drinking-water quality. Vol. 1, Recommendations, 3rd ed. (2004). (Accessed 22 December 2020); https://apps.who.int/iris/handle/10665/42852

37. Hakkila, P. Utilization of residual forest biomass. In Utilization of Residual Forest Biomass 352-477 (Springer Berlin Heidelberg, 1989). https://doi.org/10.1007/978-3-642-74072-5_8

38. Obernberger, I. \& Supancic, K. Possibilities of ash utilisation from biomass combustion plants. In Proceedings of the 17th European Biomass Conference \& Exhibition Hamburg. vol. 29 (2009).

39. Bachmaier, H., Kuptz, D. \& Hartmann, H. Wood ashes from grate-fired heat and power plants: Evaluation of nutrient and heavy metal contents. Sustainability. 13, 5482. https://doi.org/10.3390/su13105482 (2021).

40. Zając, G., Szyszlak-Bargłowicz, J. \& Szczepanik, M. Influence of biomass incineration temperature on the content of selected heavy metals in the ash used for fertilizing purposes. Appl. Sci. 9, 1790. https://doi.org/10.3390/app9091790 (2019).

41. Kuokkanen, M., Pöykiö, R., Kuokkanen, T. \& Nurmesniemi, H. Wood ash-A potential forest fertilizer. In Proceeding of the EnePro Conference, University of Oulu. 9-93 (2009).

42. High, K. E. \& Penkman, K. E. A review of analytical methods for assessing preservation in waterlogged archaeological wood and their application in practice. Herit. Sci. 8, 1-33. https://doi.org/10.1186/s40494-020-00422-y (2020).

43. Silva, F. C., Cruz, N. C., Tarelho, L. A. \& Rodrigues, S. M. Use of biomass ash-based materials as soil fertilisers: Critical review of the existing regulatory framework. J. Clean. Prod. 214, 112-124. https://doi.org/10.1016/j.jclepro.2018.12.268 (2019).

44. Kumar, D., Shukla, V., Kumar, S., Ram, R. B. \& Kumar, N. Metal pollution index and daily dietary intake of metals through consumption of vegetables. Int. J. Environ. Sci. Technol. 17, 3271-3278. https://doi.org/10.1007/s13762-019-02594-y (2020).

45. Al-Taani, A. A., Nazzal, Y. \& Howari, F. M. Assessment of heavy metals in roadside dust along the Abu Dhabi-Al Ain National Highway, UAE. Environ. Earth Sci. 78, 1-13. https://doi.org/10.1007/s12665-019-8406-x (2019).

\section{Acknowledgements}

This work was supported by the Federal Ministry of Education and Science, FB\&H through the research grant scheme (contract No 05-39-2554-1/19).

\section{Author contributions}

M.P. conceived the research work, sampling design, preparation of samples for analysis and drafted the manuscript. M.S. sample collection, preparation of samples for analysis and writing the manuscript. J.S. performed analysis and contributed to the writing of the manuscript. A.S. performed the calculation for risks analysis. S.B. and S.S.H. interpreted the results and were part of the manuscript preparation. F.S. visualization, and critically revised the manuscript.

\section{Competing interests}

The authors declare no competing interests.

\section{Additional information}

Correspondence and requests for materials should be addressed to M.P.

Reprints and permissions information is available at www.nature.com/reprints.

Publisher's note Springer Nature remains neutral with regard to jurisdictional claims in published maps and institutional affiliations.

Open Access This article is licensed under a Creative Commons Attribution 4.0 International License, which permits use, sharing, adaptation, distribution and reproduction in any medium or format, as long as you give appropriate credit to the original author(s) and the source, provide a link to the Creative Commons licence, and indicate if changes were made. The images or other third party material in this article are included in the article's Creative Commons licence, unless indicated otherwise in a credit line to the material. If material is not included in the article's Creative Commons licence and your intended use is not permitted by statutory regulation or exceeds the permitted use, you will need to obtain permission directly from the copyright holder. To view a copy of this licence, visit http://creativecommons.org/licenses/by/4.0/.

(C) The Author(s) 2021 